Association for Information Systems

AIS Electronic Library (AISeL)

Wirtschaftsinformatik 2021 Proceedings

Track 5: Digitization and society - even in times

of Corona

\title{
The Role of Fear and Trust when Disclosing Personal Data to Promote Public Health in a Pandemic Crisis
}

Kirsten Hillebrand

Universität Bremen

Follow this and additional works at: https://aisel.aisnet.org/wi2021

Hillebrand, Kirsten, "The Role of Fear and Trust when Disclosing Personal Data to Promote Public Health in a Pandemic Crisis" (2021). Wirtschaftsinformatik 2021 Proceedings. 2.

https://aisel.aisnet.org/wi2021/VDigitization/Track05/2

This material is brought to you by the Wirtschaftsinformatik at AIS Electronic Library (AISeL). It has been accepted for inclusion in Wirtschaftsinformatik 2021 Proceedings by an authorized administrator of AIS Electronic Library (AISeL). For more information, please contact elibrary@aisnet.org. 


\title{
The Role of Fear and Trust when Disclosing Personal Data to Promote Public Health in a Pandemic Crisis
}

\author{
Kirsten Hillebrand ${ }^{1}$ \\ ${ }^{1}$ University of Bremen, Faculty of Business Studies and Economics, Bremen, Germany \\ post@kirstenhillebrand.de
}

\begin{abstract}
During the 2020 pandemic crisis, state surveillance measures violated citizens' privacy rights to track the virus spread. Rather little civic protest resulted-"safety first"? Indeed, many state measures were implemented during the crisis without ever having been discussed in advance of the event of a crisis, which may raise ethical considerations, as individual consent to data disclosure may change while experiencing fear. This paper investigates citizens' consent to voluntary and legally obliging data disclosure to the state and what drives their consent. Results from an online survey conducted with 1,156 respondents during the onset of the crisis in Germany in mid-March show that (1) fear increases consent to voluntary data disclosure, (2) fear increases consent to legally obliging data disclosure directly and indirectly by fostering distrust in others, and (3) trust in the government increases voluntary and legally obliging data disclosure.
\end{abstract}

Keywords: data privacy, fear, trust, COVID-19, data disclosure.

\section{Introduction}

In early 2020 the world started to change in the face of the coronavirus. While in certain regions of China the first mass quarantines and the cancellations of the Chinese New Year celebrations have already been ordered in January [37], many Western nations imposed major restrictions especially in March as a response to the exponentially rising infection numbers: Italy locks its borders and closes all schools and universities [44], France introduces a curfew in which citizens are not allowed to leave their homes without a respective certificate [46]. U.S. President Trump declares a national state of emergency [8] and the Dax faces its highest loss since the September 11 terrorist attacks [20]. Germany, like many other countries, decrees the drastic restriction of social contacts and closes down gastronomy and certain service companies [9]. Spain even closes all "non-essential businesses" [29]. In times of crisis, the state is expected to take action. In most Western democracies, governments restricted basic citizens' rights, though little protest resulted; citizens likely were apt to think that security comes first. In a pandemic crisis, different rules seem to apply-but is this the case even for data protection? Although international politicians have addressed the crisis in various ways, one 
measure was popular: the use of public information to control the spread of the virus. Some states seem to put safety first and insisted on state supervision of all citizens, whereas others relied on voluntary approaches. In Taiwan, for example, people entering the country were monitored by their mobile data to ensure that they were complying with the quarantine. South Korea had authorities record location data of infected people using GPS tracking and compare their movement with credit card transactions and images from video surveillance. Israel allowed its secret service to analyze mobile phone data of millions of users to track movement flows. In Germany, Deutsche Telekom transmitted a one-time set of mobile data to the Robert Koch Institute (RKI) in mid-May to analyze the spread of the virus [43]. The German Minister of Health recommended continuous tracking of citizens' location data to identify people who came in contact with infected people. However, after criticism from data protectionists and the German Minister of Justice, a draft for a law to this effect was stopped [19]. Similar to Singapore, Germany then followed a voluntary approach [40]. A perquisite for this approach was that users voluntarily disclose their data. At the time this paper was prepared, the discussion in Germany concerned in particular the voluntary sharing of location and health data. The current solution, a Bluetooth-based app without location data, was not considered at that time.

An examination of South Korea, for example, shows that the use of data could indeed have the potential to contain the virus. Although South Korea is democratically governed and, as of this writing, could avoid a lockdown, the spread of the virus is widely controlled. In addition, scientists of the German Academy of Natural Scientists Leopoldina explicitly recommend the use of data [25]. However, despite its apparent potential, the use of data to contain the virus remains internationally controversial from a data protection standpoint. Data protectionists warn that tracking data during the crisis endangers people's privacy far beyond the pandemic crisis period [2]. E.g., location data can serve as a diagnostic measure of sensitive individual attributes such as religious or political views and possible health concerns [15]. The European Union has therefore classified location data as "personal data" in the General Data Protection Regulation. In the course of the 2020 pandemic crisis, it is striking that a majority of governmental data collection measures are discussed ad hoc and implemented in the middle of a global emergency, a time when people may be fearing for their health, the health of loved ones, and consequences for the public. Data protection advocates warn that governments might use the crisis to realize measures of data collection and state surveillance that they may not have been able to enforce outside the exceptional situation [4]. Would protests have been greater if these measures were discussed outside the crisis, considering that preferences change when experiencing fear $[26,27,47]$ ?

With regard to their safety, citizens face a trade-off: If they make use of the state's voluntary services and thereby disclose their data, the virus can be better controlled without state violation of privacy rights. However, individuals cannot know if a sufficient number of people will comply with these voluntary services to control the virus. Are people willing to take that risk? Or, in times of crisis and fear, 
do they prefer mandatory data sharing of all citizens to ensure safety? If so, the virus may be better controlled, but the government will violate fundamental privacy rights by surveilling citizens' location without prior individual consent. This paper aims to contribute to a better understanding of what drives preferences of the potentially harmed parties in this trade-off-the citizens. The study is carried out in the context of the 2020 pandemic crisis with German citizens with regard to location data tracking. In this paper I examine how individuals may prefer data sharing over privacy, and in particular whether German citizens are more likely to agree to voluntary or mandatory data sharing to the state if their goal is to ensure safety. I therefore pose the following research question:

RQ: How do fear and trust influence the willingness to disclose personal data to the state in order to promote public health in a pandemic crisis?

\section{Theoretical Background and Research Model}

Literature suggests that the individual decision to disclose data is based on a costeffectiveness analysis, such that data are released if the expected positive outcomes exceed the costs (i.e., the privacy risk). This logic also applies to the disclosure of location data [10]. Researchers have investigated how the willingness to self-disclose location data varies with the nature of the generated benefit. They distinguish between "symbolic" or "hedonic" benefits (e.g., additional values such as better service, personalization of offers) and "utilitarian" benefits (e.g., goods, monetary advantages) [42,48]. However, extant literature on the disclosure of data based on a privacy calculus neglects crucial particularities of a pandemic crisis. First, the benefit a person gains by voluntary disclosing his or her location is uncertain and delayed. In this situation, whether someone gains an advantage from data disclosure depends on the behavior of others [6]. In this paper's scenario, the spread of the virus can only be controlled without governmental coercion if a sufficient number of people voluntarily disclose their location. Second, the benefit is of varying value for each person in a pandemic crisis. The added value depends on what negative consequences a person anticipates if the spread of the virus cannot be controlled. These particularities reveal a social dilemma: If all citizens voluntarily disclose their location, the spread of the virus can be controlled better, and government coercion is avoided. However, every citizen has an incentive to deviate and to benefit from virus control without restricting his or her privacy. Without control of the virus, people are worse off than if they had cooperated. State surveillance of location data without prior consent of the citizens would solve this dilemma. However, state surveillance also means the government violates citizens' basic privacy rights. This study builds on literature that takes the perspective of a privacy calculus to analyze the decision to disclose data. However, to examine the extent to which citizens prefer their privacy rights to be violated by the state in a pandemic crisis for the sake of safety, the study also focuses on literature on social dilemmas, 
especially on psychological factors of decisions in "give-some" dilemmas and public good games with imperfect information and uncertainty.

Uncertainty and Trust. Extensive literature has examined interpersonal factors associated with cooperation in public good dilemmas. One factor of consensus is trust. Individuals who trust others show higher rates of cooperation than individuals with low trust in others $[7,23]$. Trust is especially relevant in decisions under uncertainty [49]. Respondents in this survey evaluated their consent to state surveillance with imperfect information and under two types of uncertainty: environmental uncertainty (i.e., uncertainty about the situation and conditions for obtaining the public good) and social uncertainty (i.e., uncertainty about the decisions of others) [34]. The current study focuses on social uncertainty. The common favorable outcome will be achieved if the virus spread is better controlled through location tracking without state coercion. Whether control is realized depends on socially uncertain decisions of two groups, fellow citizens and government officials, as it is uncertain whether fellow citizens would consent to voluntary data disclosure and whether government officials would use location data only to actually control the spread of the virus. Considering the role of trust in making decisions under uncertainty, this discussion leads to the following hypotheses about the effect of trust on a citizen's consent to be voluntarily surveilled by the state:

$\boldsymbol{H}_{1 a}$ : Interpersonal trust ( $\left.T_{i p}\right)$ increases consent to voluntary data disclosure to the state $\left(C_{v d}\right)$.

$\boldsymbol{H}_{1 b}$ : Trust in the government to actually use the data to control the spread of the virus $\left(T_{\text {gov }}\right)$ increases consent to voluntary data disclosure to the state $\left(C_{v d}\right)$.

A review of the literature also leads to competing hypotheses about the effect of interpersonal trust on the consent to legally obliging data disclosure. People are often willing to accept personal disadvantages and even prefer institutions that monitor cooperation so that the common good can be promoted $[14,18]$. If others are trusted to jointly achieve the control of the virus spread through voluntary cooperation, state coercion becomes obsolete and illegitimate. If others are not trusted, state coercion may be preferred to ensure cooperation and safety.

$\boldsymbol{H}_{2 a}$ : Interpersonal trust ( $T_{i p}$ ) decreases consent to legally obliging data disclosure to the state $\left(C_{o d}\right)$.

$\boldsymbol{H}_{2 b}$ : Trust in the government to actually use the data to control the spread of the virus $\left(T_{\text {gov }}\right)$ increases consent to legally obliging data disclosure to the state $\left(C_{o d}\right)$.

Payoff Levels and Group Identity. Research in which experimenters have manipulated payoff levels shows that unequal payoffs influence cooperation [22]. In a pandemic crisis, payoff levels are determined by the real-world situation, in which payoffs are not only uncertain but also unequal. Individuals benefit in 
varying degrees from a controlled virus spread. Similarly, the negative consequences for individuals vary if the spread of the virus is not controlled. In the context of the current study, survey responses indicate that fear of the consequences of the novel coronavirus determine the perceived payoff level. When making decisions, people's brains are configured to divide people into "us" and "them" [17] and they work in a dual process: fast (i.e., based on gut feeling and intuition) and slow (i.e., analytically and rationally). Judgment based on gut feeling increases intragroup cooperation but leads to an in-group-preferential bias. People especially judge intuitively in situations with imperfect information and under uncertainty, such as the 2020 pandemic crisis [45]. Thus, people may perceive a payoff level differently, depending on which group profits from it. In public good games, too, the willingness to cooperate depends on the group affiliation of the players. If the out-group profits more from a good than its own group, the cooperation rate decreases [6, 35]. The following hypotheses on the influence of unequal payoffs on the consent to surveillance, therefore, differentiate between two groups: the in-group, one's self and closest people, and the out-group, the country's population.

$\boldsymbol{H}_{3 a}:$ Fear $\left(F_{i n} / F_{\text {out }}\right)$ increases consent to voluntary data disclosure to the state $\left(C_{v d}\right)$. Fear for self and closest people $\left(F_{\text {in }}\right)$ has a greater impact than fear for the population ( $F_{\text {out }}$ ).

$\boldsymbol{H}_{3 b}$ : Fear $\left(F_{\text {in }} / F_{\text {out }}\right)$ increases consent to legally obliging data disclosure to the state $\left(C_{o d}\right)$. Fear for self and closest people $\left(F_{\text {in }}\right)$ has a greater impact than fear for the population $\left(F_{\text {out }}\right)$.

The Interplay of Fear and Trust. Literature on cooperation shows an interplay of fear and trust. For example, researchers examined high and low trusters' responses to fear in a public good dilemma and found that when fear is present in a game, people with a high level of trust cooperate more than people with a low level of trust [35]. However, fear in this research refers to the possibility of not receiving a payoff despite cooperation. In the context of a pandemic crisis, fear rather is an indicator for the perceived consequences if the virus is not controlled. As described, the negative consequences of the novel coronavirus are not only uncertain but also unequal. To cover this particularity, the current study follows the argumentation of the security dilemma, whose original concept has been further developed for current global security challenges (e.g., the cyber security dilemma) $[3,21]$. The security dilemma suggests that states achieve the highest level of security if all states cooperate, but in the real world they do not, because they have incentives to defect. The more a state fears the consequences of defection, (1) the greater the state's incentive to join a larger entity and (2) the greater its distrust in other states. States that can afford a zero payoff have greater trust in others and cooperate more often. In terms of the pandemic crisis, this means that people who greatly fear the consequences of the novel coronavirus can less afford to let the virus spread, and thus can less afford to trust others and are more inclined to consent to regulated surveillance. 
$H_{4 a}:$ Fear $\left(F_{\text {in }} / F_{\text {out }}\right)$ indirectly decreases consent to voluntary data disclosure to the state $\left(C_{v d}\right)$ by decreasing interpersonal trust $\left(T_{i p}\right)$.

$\boldsymbol{H}_{4 b}:$ Fear $\left(F_{\text {in }} / F_{\text {out }}\right)$ indirectly increases consent to legally obliging data disclosure to the state $\left(C_{o d}\right)$ by decreasing interpersonal trust $\left(T_{i p}\right)$.

Figure 1 presents a graphic depiction of the research model.

Figure 1. Research Model

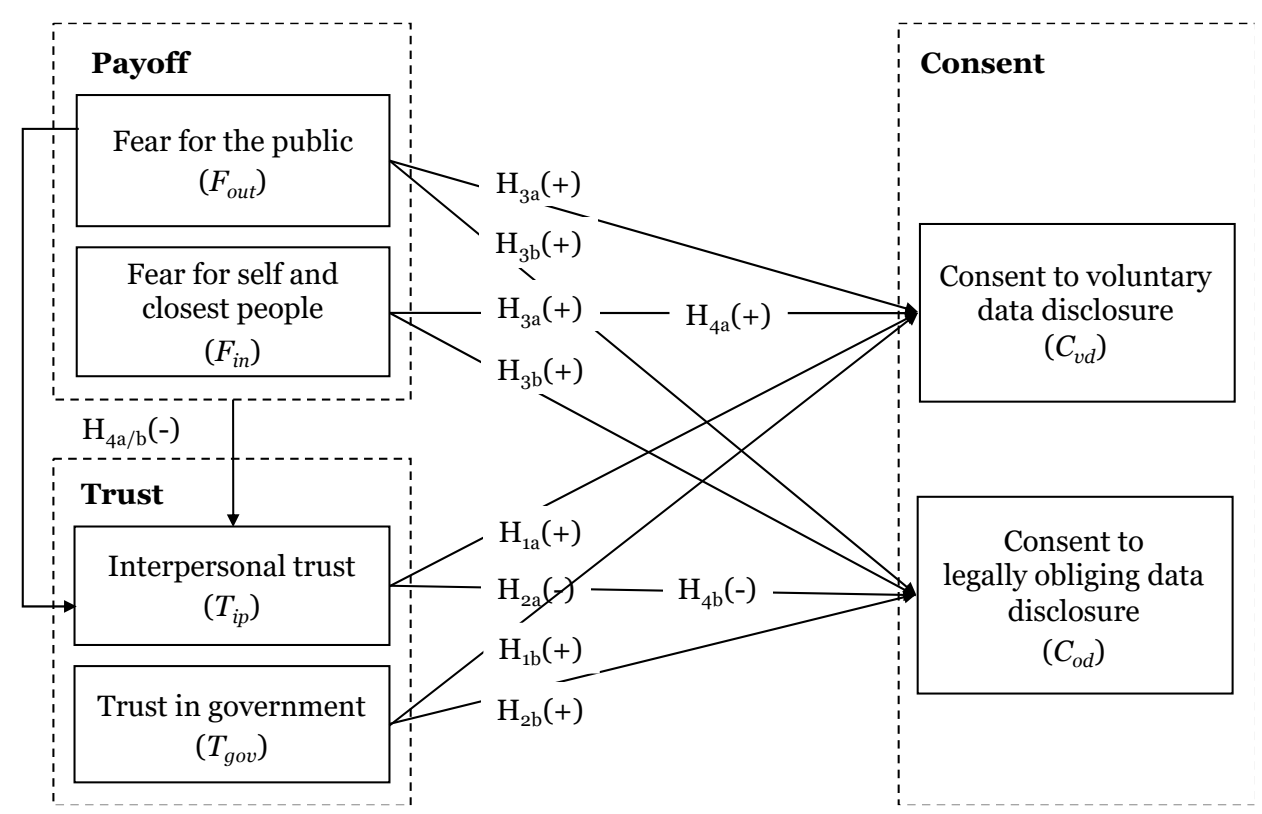

\section{Method}

Data Collection and Sample Description. The data were collected via an online survey in the period from March 18 to March 29, 2020, when the pandemic crisis in Germany intensified such that the increase in infections changed from moderate to exponential. While the first person in Germany died of COVID-19 on March 8, approx. three weeks later, on March 31, there were already 584 reported deaths [39]. Also, the number of new infections per day reached the first wave's peak during the survey period on March 28 with 6,294 newly infected persons [39]. There was heated political and public debate on possible government measures. The German government implemented many actual measures during the course of the survey, such as the drastic restriction of social contacts and the closing of gastronomy and selected service businesses on March 22 [9]. The day before the survey launched, it became public that the German mobile network operator 
Telekom shared a one-time set of mobile phone data of German citizens with the RKI [43]. At the time of the survey there was no public discussion about the governmental "Corona-Warn-App" as it exists today. The survey period during the crisis outbreak is crucial to the significance of this study's results. During the outbreak, it was still uncertain what measures the state would conclusively introduce and how great the threat of the novel coronavirus really was to the individual; in short, the period was characterized by uncertainty. After the outbreak phase, participants' responses could be influenced by the extent to which the measures implemented up to that point were effective and what damage the virus actually caused to individuals. The advantage of surveying during the outbreak therefore is that the anticipated benefit of location data to contain the virus is less dependent on country-specific government measures and the development of the crisis. The study results are therefore more general and allow for better implications. Another advantage of surveying during the outbreak is that, due to the increasing state restrictions on civil rights during that period, participants could assume that the government might actually introduce surveillance measures, which contributes to the credibility and realistic nature of the survey content.

The survey respondents were recruited via social media. To obtain a representative sample of the German population, the ad was targeted to all users registered on Facebook and Instagram in Germany. Studies investigating the representativeness of social media samples for the general population provide contradictory results. While Twitter and Facebook users in the UK differ from the general population in terms of age, gender and education, they are representative of values and political behavior [30]. An evaluation of Facebook advertising to generate a representative sample of Canadians for a health survey concludes that the sample is representative of geography, age and income. However, the sample was over-representative of women and higher levels of education [41]. Other scientists compared responses to an online survey on climate change public opinion between two U.S. samples: one was generated with Facebook ads, one based on a high-quality online survey panel. Although the social media sample was not representative of the U.S. population, the responses were mostly identical to those of the high-quality sample [50]. Overall, results suggest that using the Facebook Ad Network to recruit participants, despite a potential lack of representativeness, is suitable for querying population-level public opinion.

The call to participate in the survey appeared in various ad formats such as a "sponsored story" and "sponsored post". The users to whom the ad was displayed were randomly selected. Randomization was implemented by deactivating the Facebook feature of displaying ads optimized for cost efficiency. The survey advertisements were displayed to a total of 40,584 German users (on average 1.15 times per user) on Facebook and Instagram. Of these people, 2,705 clicked on the survey link and were redirected to the survey's introductory text (click rate of 6.67\%). 1,253 people have started to actually fill out and 1,156 completed the survey (dropout rate of $7.74 \%$ ). Participation was voluntary and not compensated. Respondents were randomly assigned to one of two survey 
versions, which differed only in the dependent variable $\left(C_{v d} / C_{o d}\right)$. Responses from individuals were excluded from the data set if (1) they answered the survey in less than a minute, (2) answers indicated random clicking (maximum or minimum values selected for all answers), (3) they were under 18 years of age, or (4) they submitted unrealistic answers (e.g., age over 100 years).

In total, 889 participants answered all survey questions without exceptions and irregularities. Data provided by this group serve to test Hypotheses 1-4. The sample consists of $62 \%$ female, $29 \%$ male, and $1 \%$ diverse-gendered respondents, with $9 \%$ preferring not to answer. The median age of the respondents is 37 years, with the youngest being 18 years and the oldest 75 years. The majority of the respondents has high vocational training $(26 \%)$ or a school diploma $(21 \%)$, followed by a graduate degree (17\%). $36 \%$ of the respondents, in approximately equal parts (between $6 \%$ and $9 \%$ ), reported attaining less than a high school diploma, having attended college, having a bachelor's degree, or not fitting into any of the answers, and $4 \%$ of the participants preferred not to answer. The mean net annual income of the respondents is " $15,001 €$ to $25,000 €$ " (minimum "less than 5,000€", maximum "more than 100,000€"). Respondents indicated their political views on a slider from 1 ("left") to 20 ("right"). The mean political view is 8 , thus skewing slightly more left.

Measures. All independent $\left(T_{i p}, T_{g o v}, F_{i n}, F_{\text {out }}\right)$ and dependent $\left(C_{v d}, C_{o d}\right)$ variables were measured using a 1-20 slider. The language to measure the variables fear, consent, and trust in government is based on Awad et al.'s German question items in the "Moral Machine Experiment" [1]. These items used the wording "To what extent ..." on a slider with extreme point labels of "very little" and "very much" and were modified from the original version to fit the context of a pandemic crisis (pretested with five people). The variables on interpersonal trust $\left(T_{i p}\right)$ and political views were collected using the original wording of the German socioeconomic panel. The control variables for gender, education, net annual income, and age were adopted from Awad et al. [1] without any modifications. To control for possible influences by daily events, timing of participation, coded in 12-hour intervals from 1 to 20 , serves as an additional control variable. Screenshots of the online questionnaire are available at this link: https://tinyurl.com/yxct485u.

\section{$4 \quad$ Data Analysis and Results}

Measurement Model. Ordinary least squares (OLS) regressions were used to test Hypotheses 1-4. Data were checked for various parameters before performing the regressions. None of the regression models have autocorrelation based on values of the Durbin-Watson statistic. Pearson correlation coefficients used to check for possible multicollinearity indicated that all variable correlation coefficients are lower than .7; the highest correlation (.649) manifested between fear for self and loved ones and fear for the population. All other correlations are below .355. Graphical visualization confirmed variance equality and normal 
distribution of the residuals. Two regression models served to test Hypotheses 13: Model 1 uses consent to voluntary data disclosure $\left(C_{v d}\right)$, and Model 2 uses consent to state surveillance $\left(C_{o d}\right)$ as the dependent variable. $C$ is a vector of variables, including age, education, income, political views, gender, and day of measurement as baseline conditions.

$$
\begin{aligned}
& \boldsymbol{C}_{v d}=\beta_{0}+\beta_{1} F_{\text {in }}+\beta_{2} F_{\text {out }}+\beta_{3} T_{\text {ip }}+\beta_{4} T_{\text {gov }}+\beta_{5} C+\varepsilon . \\
& \boldsymbol{C}_{\text {od }}=\beta_{0}+\beta_{1} F_{\text {in }}+\beta_{2} F_{\text {out }}+\beta_{3} T_{\text {ip }}+\beta_{4} T_{\text {gov }}+\beta_{5} C+\varepsilon .
\end{aligned}
$$

A third set of regression models served as a mediation analysis to test Hypotheses $4_{\mathrm{a}}$ and $4_{\mathrm{b}}$. Mediation is considered present when the following four conditions are met [28]: First, the fear variable $\left(F_{\text {in }} / F_{\text {out }}\right)$ has a significant effect on consent to voluntary data disclosure $\left(C_{v d}\right)$ in Equation 1 . Second, the fear variable $\left(F_{\text {in }} / F_{\text {out }}\right)$ has a significant effect on the mediator variable interpersonal trust $\left(T_{i p}\right)$ in Equation 2. Third, in Equation 3 (identical to Model 1) the mediator variable $T_{i p}$ has a significant effect on $C_{v d}$, and fourth, the coefficient of $\beta_{1}$ and the coefficient of $\beta_{2}$ must be smaller in absolute terms in Equation 3 than in Equation 1. The mediation for consent to state surveillance $\left(C_{o d}\right)$ is identified analogously (Equation 3 identical to Model 2).

$$
\begin{gathered}
C_{v d}=\beta_{0}+\beta_{1} \boldsymbol{F}_{\text {in }}+\beta_{2} \boldsymbol{F}_{\text {out }}+\beta_{3} T_{\text {gov }}+\beta_{4} C+\varepsilon . \\
T_{i p}=\beta_{0}+\beta_{1} \boldsymbol{F}_{\text {in }}+\beta_{2} \boldsymbol{F}_{\text {out }}+\beta_{3} T_{\text {gov }}+\beta_{4} C+\varepsilon . \\
\boldsymbol{C}_{\boldsymbol{v} \boldsymbol{d}}=\beta_{0}+\beta_{1} F_{\text {in }}+\beta_{2} F_{\text {out }}+\beta_{3} T_{i p}+\beta_{4} T_{\text {gov }}+\beta_{5} C+\varepsilon .
\end{gathered}
$$

Structural Model and Hypotheses Testing. Table 1 summarizes the OLS testing results. $\mathrm{H}_{1 a}$ predicted a positive relationship of interpersonal trust $\left(T_{i p}\right)$ and consent to voluntary data disclosure. Regression results are not significant; thus, $\mathrm{H}_{1 \mathrm{a}}$ is not supported. By contrast, interpersonal trust and consent to state surveillance show a significant, negative relationship, in support of $\mathrm{H}_{2 a}$. Trust in government significantly increases both consent to voluntary data disclosure and consent to state surveillance, in support of $\mathrm{H}_{1 \mathrm{~b}}$ and $\mathrm{H}_{2 \mathrm{~b}}$. Fear for self and closest people significantly increases consent to voluntary data disclosure, while fear for the public does not. Although $\mathrm{H}_{3 \mathrm{a}}$ suggested an influence of fear for both the ingroup and the out-group, the influence of in-group fear was expected to be stronger. Thus, $\mathrm{H}_{3 \mathrm{a}}$ is considered supported. In line with $\mathrm{H}_{3 \mathrm{~b}}$, fear for self and closest people and fear for the public significantly increase consent to legally obliging data disclosure; however, fear for the public has a higher impact than fear for self and closest people, thus offering only partial support for $\mathrm{H}_{3 \mathrm{~b}}$. 
Table 1. Results of OLS analyses

\begin{tabular}{|c|c|c|c|c|c|c|}
\hline & \multirow{2}{*}{$\begin{array}{l}\text { Model } 1 \\
d v: C \_v d\end{array}$} & \multirow{2}{*}{$\begin{array}{l}\text { Model } 2 \\
d v: C \_o d \\
\end{array}$} & \multicolumn{4}{|c|}{ Set of Models for Mediation Analysis } \\
\hline & & & $\begin{array}{c}\text { equation } 1 \\
d v: C \quad v d\end{array}$ & $\begin{array}{c}\text { equation } 2 \\
d v: T \text { ip }\end{array}$ & $\begin{array}{l}\text { equation } 1 \\
d v: C \text { od }\end{array}$ & $\begin{array}{c}\text { equation } 2 \\
d v: T \text { ip }\end{array}$ \\
\hline Intercept & $\begin{array}{c}1.104 \\
(2.115)\end{array}$ & $\begin{array}{c}1.784 \\
(1.917)\end{array}$ & $\begin{array}{c}1.208 \\
(2.051)\end{array}$ & $\begin{array}{c}7.627 * * * \\
(1.513)\end{array}$ & $\begin{array}{c}3.189 \\
(1.850)\end{array}$ & $\begin{array}{c}\mathbf{8 . 8 0 2} * * * \\
(1.411)\end{array}$ \\
\hline F_out & $\begin{array}{c}0.135 \\
(0.086)\end{array}$ & $\begin{array}{c}\mathbf{0 . 3 4 1} * * * \\
(0.082)\end{array}$ & $\begin{array}{c}0.137 \\
(0.085)\end{array}$ & $\begin{array}{l}-\mathbf{- 0 . 1 3 8}^{*} \\
(0.063)\end{array}$ & $\begin{array}{c}\mathbf{0 , 3 5 6} * * * \\
(0.082)\end{array}$ & $\begin{array}{l}-0.095 \\
(0.062)\end{array}$ \\
\hline F_in & $\begin{array}{c}\mathbf{0 . 2 4 4 * *} \\
(0.079)\end{array}$ & $\begin{array}{l}\mathbf{0 . 1 5 7 *} \\
(0.073)\end{array}$ & $\begin{array}{c}\mathbf{0 . 2 4 7 * *} \\
(0.077)\end{array}$ & $\begin{array}{c}\mathbf{- 0 . 2 5 7 * * *} \\
(0.057)\end{array}$ & $\begin{array}{c}\mathbf{0 . 1 9 4 * *} \\
(0.072)\end{array}$ & $\begin{array}{c}-\mathbf{0 . 2 3 2} * * * \\
(0.055)\end{array}$ \\
\hline T_ip & $\begin{array}{c}-0.014 \\
(0.066)\end{array}$ & $\begin{array}{c}\mathbf{- 0 . 1 6 0 * *} \\
(0.062)\end{array}$ & & & & \\
\hline T_gov & $\begin{array}{c}\mathbf{0 . 3 7 2 * * *} \\
(0.056)\end{array}$ & $\begin{array}{c}\mathbf{0 . 1 4 3} * * * \\
(0.033)\end{array}$ & $\begin{array}{c}\mathbf{0 . 3 7 2} * * * \\
(0.056)\end{array}$ & $\begin{array}{l}-0.011 \\
(0.041)\end{array}$ & $\begin{array}{c}\mathbf{0 . 1 4 1} * * * \\
(0.033)\end{array}$ & $\begin{array}{c}0.017 \\
(0.025)\end{array}$ \\
\hline age & $\begin{array}{c}0.033 \\
(0.025)\end{array}$ & $\begin{array}{c}\text { 0.056* } \\
(0.025)\end{array}$ & $\begin{array}{c}0.033 \\
(0.025)\end{array}$ & $\begin{array}{c}-0.032 \\
(0.018)\end{array}$ & $\begin{array}{l}\text { 0.056* } \\
(0.025)\end{array}$ & $\begin{array}{l}-0.001 \\
(0.019)\end{array}$ \\
\hline education & $\begin{array}{c}0.105 \\
(0.200)\end{array}$ & $\begin{array}{c}-0.231 \\
(0.178)\end{array}$ & $\begin{array}{c}0.105 \\
(0.200)\end{array}$ & $\begin{array}{c}0,010 \\
(0.148)\end{array}$ & $\begin{array}{l}-0.275 \\
(0.178)\end{array}$ & $\begin{array}{c}0.277 \\
(0.136)\end{array}$ \\
\hline gender & $\begin{array}{l}-0.072 \\
(0.686)\end{array}$ & $\begin{array}{c}0.134 \\
(0.639)\end{array}$ & $\begin{array}{l}-0.081 \\
(0.684)\end{array}$ & $\begin{array}{c}0.652 \\
(0.505)\end{array}$ & $\begin{array}{c}0.146 \\
(0.643)\end{array}$ & $\begin{array}{l}-0.074 \\
(0.490)\end{array}$ \\
\hline income & $\begin{array}{l}-0.079 \\
(0.176)\end{array}$ & $\begin{array}{l}-0.129 \\
(0.161)\end{array}$ & $\begin{array}{l}-0.083 \\
(0.175)\end{array}$ & $\begin{array}{l}\text { 0.306* } \\
(0.129)\end{array}$ & $\begin{array}{l}-0.125 \\
(0.162)\end{array}$ & $\begin{array}{l}-0.022 \\
(0.123)\end{array}$ \\
\hline political view & $\begin{array}{c}0.131 \\
(0.081)\end{array}$ & $\begin{array}{c}0.102 \\
(0.075)\end{array}$ & $\begin{array}{c}0.132 \\
(0.081)\end{array}$ & $\begin{array}{l}-0.069 \\
(0.059)\end{array}$ & $\begin{array}{c}0.107 \\
(0.075)\end{array}$ & $\begin{array}{l}-0.030 \\
(0.057)\end{array}$ \\
\hline day & $\begin{array}{l}-0.068 \\
(0.055)\end{array}$ & $\begin{array}{c}-\mathbf{- 0 . 1 1 9 *} \\
(0.055)\end{array}$ & $\begin{array}{l}-0.067 \\
(0.055)\end{array}$ & $\begin{array}{l}-0.051 \\
(0.041)\end{array}$ & $\begin{array}{l}-\mathbf{1 . 0 9 *} \\
(0.055)\end{array}$ & $\begin{array}{l}-0.061 \\
(0.042)\end{array}$ \\
\hline
\end{tabular}

Notes. Unstandardized coefficients and standard deviations are shown. $p$-values are reported as follows: ${ }^{*} p<.05 ;{ }^{* *} p<.01 ;{ }^{* * *} p<.001$. Dashed lines indicate no significance. All models are estimated with an OLS linear regression. Model 1 and mediation analysis on $C_{v d}: \mathrm{N}_{1}=430$, Model 2 and mediation analysis on $C_{o d}: \mathrm{N}_{2}=459$.

Mediation analyses using several regressions according to MacKinnon et al. [28] offer further results. $\mathrm{H}_{4 a}$ predicted that fear would indirectly decrease consent to voluntary data disclosure by decreasing interpersonal trust. As interpersonal trust has no significant impact on consent to voluntary data disclosure, mediation according to $\mathrm{H}_{4 \mathrm{a}}$ is not supported. $\mathrm{H}_{4 \mathrm{~b}}$ predicted that fear would indirectly increase consent to state surveillance by decreasing interpersonal trust. For fear for self and closest people, all four conditions are met. 
First, fear $\left(F_{\text {in }}\right)$ increases consent to state surveillance in Equation $1\left(\beta_{1}=\right.$ $.194, p=.007)$. Second, fear $\left(F_{i n}\right)$ decreases interpersonal trust in Equation 2 $\left(\beta_{1}=.232, p<.001\right)$. Third, interpersonal trust decreases consent to state surveillance in Equation $3\left(\beta_{1}=.160, p=.010\right)$, and fourth, $\beta_{1}$ is smaller in Equitation 3 (Model 2) than in Equitation 1. Thus, fear $\left(F_{\text {in }}\right)$ indirectly increases consent to state surveillance by decreasing interpersonal trust. Fear for the public does not indirectly increase consent to state surveillance by decreasing trust, as condition 2 is not met $\left(\beta_{2}=-.095, p=.127\right)$. Therefore, mediation according to $\mathrm{H}_{4 \mathrm{~b}}$ is supported for in-group fear. Figure 2 summarizes the significant variable relationships.

Figure 2. Summary of hypothesis testing

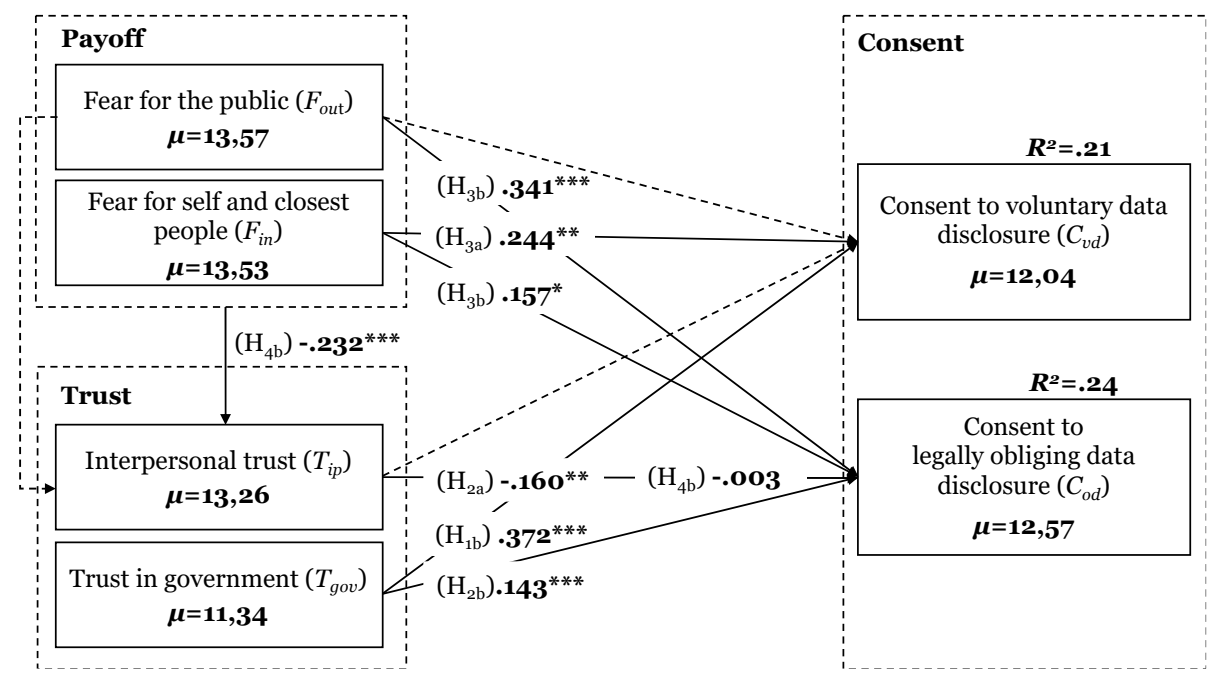

Notes. Goodness of fit, mean, and unstandardized significant coefficients are shown. pvalues are reported as follows: ${ }^{*} p<.05 ;^{* *} p<.01 ;^{* * *} p<.001$. Dashed lines indicate no significance.

\section{Discussion}

The regression results confirm $\mathrm{H}_{1 b}, \mathrm{H}_{2 a}, \mathrm{H}_{2 b}, \mathrm{H}_{3 a}$ and partially $\mathrm{H}_{3 b}$ and $\mathrm{H}_{4 b}$. In summary, the main testing results are: (1) higher interpersonal trust is associated with less consent to voluntary data disclosure to the state, (2) trust in the government to actually use the data to control the virus spread increases both, consent to voluntary and mandatory data disclosure to the state, (3) fear for self and closest people increases consent to voluntary data disclosure, but fear for the public does not, (4) both, in-group and out-group fear increase consent to legally 
obliging data disclosure to the state, (5) in-group fear further increases consent to state surveillance indirectly by decreasing interpersonal trust.

Limitations of the results stem from the country-specific survey. Although it is beneficial that data were collected during the outbreak of a crisis, specific daily events in Germany and cultural particularities such as the statutory health insurance system might have influenced the results. Moreover, results would have been more conclusive if the survey had additionally been conducted before the pandemic. This would allow a direct comparison of the fear and trust levels of the two survey dates and would provide clear insights of how consent preferences change while experiencing fear. It may be useful to conduct a repeating survey after the pandemic has abated, but it would remain unclear how responses would be affected by the lasting shock and country-specific measures. In addition, data are based on stated rather than revealed preferences, i.e., there may be discrepancies in the results if people actually had to share their location data. For ethical reasons, it was deliberately avoided to ask individuals to actually disclose their location, as their data would not have actually been used to contain the coronavirus.

Despite those limitations, the findings indicate that the perception of fear affects how people decide on sharing their personal data in a global crisis. It is therefore ethically questionable when people have to make the decision to disclose personal data within a crisis. Governmental officials should initiate the discussion about the handling of personal data in the context of crisis management in advance.

In fact, there have been several stakeholders who have called for a planned approach to handle personal data in crisis management in recent years. International scientists have dealt with the trade-off between security and privacy in crises in various studies. The studies often referred to terrorist crises and disaster control, but the results and political implications can easily be transferred to health crises. For example, Davis and Silver [5] find that a threat to national or personal security contributes significantly to people renouncing their civil rights. The greater the threat, the less people support civil democratic freedom. Pavone and Esposti [36] add that public opinion on surveillance technology is influenced not only by the need for security, but also by the context in which the surveillance technology is implemented. In an exploratory study of the willingness of German citizens to reduce their online privacy in favor of security in times of crisis, Reuter et al. [38] identify a cooperative group that would only do so at certain conditions. Researchers further suggest that measures concerning security and privacy should be decided with some time lag from the crisis itself. If not, overhasty decisions might unnecessarily restrict the freedom of citizens $[16,34,38]$. Despite varying methods and contexts, existing research results support those of this study. The coronavirus-induced crisis is a special situation in which decisions are potentially made differently than before or after the crisis.

Parts of the political arena have pushed the discussion about the protection of privacy in recent years. For example, the European Union invested billions of euros in security research in the early 2000s $[11,12]$. These investments included the 
research project PRISMS, which ran from 2012 to 2015 and conducted a comprehensive survey of public opinion on the trade-off between privacy and security. The aim of the project was to formulate a decision-support-system to guide the ethical political handling of the trade-off [13]. Nonetheless, there has been no uniform European regulation at the outbreak of the corona crisis. In Germany, too, some politicians recognized the importance of data privacy ahead of the crisis, including Volker Kauder, the parliamentary party leader of the CDU, Stefan Brink, the state data protection commissioner, and Sabine LeutheusserSchnarrenberger, the federal minister of justice. Also Burkhard Hirsch and Gerhart Baum have been fighting for the protection of basic privacy rights and for a surveillance-free society for many years [e.g., 24]. But in Germany, too, there has been no pre-determined regulation on how personal data may be used to foster security in the event of a crisis - yet the 2007 LÜKEX report has even identified corresponding deficiencies. The report is the result of a nationwide pandemic crisis management audit with the aim of optimizing governmental and public crisis management. The report identifies an extensive need for action in the area of "prevention" and demands a specification of legal provisions and exception regulations. In 2007, the handling of data had not been subject of the report. However, when concretizing prevention measures in response to the report, policymakers could easily have taken the handling of data into account in the following years. It remains ambiguous why the German government not only failed to respond to identified shortcomings, but also kept the report secret for a considerable time.

In contrast to other countries, Germany ultimately refrained from collecting personal data and relied on a voluntary solution based on the "Corona-Warn-App". However, it is a fact that monitoring of location data was at least considered. And indeed, in the middle of the second infection cycle, voices from industry and politics are once again calling for restrictions on data protection in order to make the "Corna-Warn-App" more effective. As Michael Hüther, Director of the Institute of the German Economy, says, "It is difficult to understand that while many basic rights are naturally infringed upon in the fight against the pandemic, data protection becomes a sacred cow“ [31]. Other politicians like Dorothee Bär and Dieter Janecek prefer to maintain the population's willingness to cooperate through trust in the government. According to the results of this study, this might be a winning strategy: trusting the government to use the data correctly increases the willingness to share data by using voluntary solutions. If enough people make use of the voluntary offer, the virus spread might be controlled without violating individual privacy. In any case, the resurgent discussion reinforces the importance of the present results.

Overall, exceptional governmental power in a crisis is reasonable in terms of national security measures. A crisis is an extreme situation in which restrictions and violations of personal rights may under certain conditions be appropriate to protect the public. Restrictions may affect economic, cultural and private domains - including the restriction of privacy through the use of personal data. Nevertheless, the results of this study illustrate - in light of relevant studies from 
other disciplines - that the context in which decisions to restrict privacy are made matters significantly. Decisions in the trade-off of security and privacy must not be forced in the middle of a crisis, both on a political and individual level.

\section{Conclusion}

This paper examined the role of fear and trust in consenting to disclose data to the state. During the 2020 pandemic crisis many states proposed data collection measures to contain the coronavirus without ever having discussed these measures transparently in advance. The timing of the governmental data collection could imply ethical concerns, as individual consent might change while experiencing fear. I conducted a survey during the outbreak of the 2020 pandemic in Germany in mid-March. Results show that fear indeed correlates with consent: Voluntary data disclosure depends on how anxious people are about themselves and their loved ones. When consenting to legally obliging data disclosure, fear plays an even greater role. Not only does fear for oneself, loved ones, and the public increase the consent to legally obliging data disclosure, but it also promotes consent by fostering distrust in others.

Despite some limitations, the results allow the conclusion that fear for oneself and others, as well as trust in others and in the state, play an important role in a global health crisis when it comes to disclosing personal data. In Germany, location tracking was hotly debated, but ultimately not carried out. The initial discussion, the data collection measures in other countries and the insights of this paper, however, show the need for defining how personal data shall be handled in crisis situations. If not, the state might violate important individual privacy rights. The public should be involved in this discussion in advance, not in the midst of a crisis while experiencing fear. The findings of this paper contribute to a better understanding of the relevance of timing when states collect personal data. Politicians and researchers should take a closer look at the various factors that can influence the citizens' consent to data disclosure in crises so that regulators can handle and collect personal data in the public's best interest.

A follow-up study is currently in progress and will compare the levels of fear, trust and consent to voluntary and mandatory disclosure of personal data during the first and second infection cycle of the coronavirus. The corresponding online experiment has been conducted at the end of October 2020 and contained identical questions as in March 2020 - with one crucial extension: Participants have randomly been primed on content of the recent public debate on how data shall be used in order to control the corona virus spread in Germany. Differences between the experimental groups will allow to draw conclusions as to whether the recent debate has changed citizens' consent to data sharing in the context of a pandemic crisis. 


\section{References}

1. Awad, E., Dsouza, S., Kim, R., Schulz, J., Henrich, J., Shariff, A., Bonnefon, J.F., Rahwan, I: The Moral Machine Experiment. Nature 563:7729, 59-64 (2018)

2. Becker, K.: Mit Apps gegen die Pandemie? Tagesschau, https://www.tagesschau.de/inland/coronavirus-forschung-bab-101.html (Accessed on 13.04.2020)

3. Buchanan, B.: The Cybersecurity Dilemma: Hacking, Trust, and Fear between Nations. Oxford University Press, New York (2016)

4. Chaos Computer Club: Geplante Corona-App ist höchst problematisch. Chaos Computer

Club, https://www.ccc.de/system/uploads/300/original/Offener_Brief_Corona_App_BMG. pdf (Accessed on 16.04.2020)

5. Davis, D.W., Silver, B.D.: Civil Liberties vs. Security: Public Opinion in the Context of the Terrorist Attacks on America. American Journal of Political Science 48:1, 28-46 (2004)

6. Dawes, R.M., McTavish, J., Shaklee, H.: Behavior, Communication, and Assumptions about Other People's Behavior in a Commons Dilemma Situation. Journal of Personality and Social Psychology 35:1, 1-11 (1977)

7. Deutsch, M.: Trust, Trustworthiness, and the F Scale. The Journal of Abnormal and Social Psychology 61:1, 138-140 (1960)

8. Deutsche Presse-Agentur: Donald Trump ruft nationalen Notstand aus. Zeit.de, https://www.zeit.de/politik/ausland/2020-03/coronavirus-donald-trumpverhaengt-nationalen-notstand (Accessed on 25.11.2020).

9. Die Deutsche Bundesregierung: Erweiterung der beschlossenen Leitlinien zur Beschränkung sozialer Kontakte - Besprechung der Bundeskanzlerin mit den Regierungscheffinen und Regierungschefs der Länder. Bundesregierung.de, https://www.bundesregierung.de/breg-de/themen/coronavirus/besprechung-derbundeskanzlerin-mit-den-regierungschefinnen-und-regierungschefs-der-laender1733248 (Accessed: 25.11.2020)

10. Dinev, T., Hart, P.: An Extended Privacy Calculus Model for E-Commerce Transactions. Information Systems Research 17:1, 61-80 (2006)

11. European Commission: On the Implementation of the Preparatory Action on the Enhancement of the European Industrial Potential in the Field of Security Research, Towards a Programme to Advance European Security Through Research and Technology. COM(2004) 72 final. Brussels European Commission (2004)

12. European Commission: Security Research: the next steps. $\operatorname{COM}(2004) 590$ final. Brussels European Commission (2004)

13. European Comission: The PRIvacy and Security MirrorS: "Towards a European framework for integrated decision making". CORDIS Forschungsergebnisse der EU, https://cordis.europa.eu/project/id/285399/de (Accessed on 15.11.2020).

14. Fehr, E., Gächter, S.: Cooperation and Punishment in Public Goods Experiments. American Economic Review 90:4, 980-994 (2000)

15. Gambs, S., Heen, O., and Potin, C.: A Comparative Privacy Analysis of Geosocial Networks. In: Proceedings of the 4th ACM SIGSPATIAL International Workshop on Security and Privacy in GIS and LBS, ACM, pp. 33-40 (2011)

16. Gethmann, C.F.: Ist die Angst ein schlechter Ratgeber? 5. Essener Forum für psychosoziale Versorgung (1996)

17. Greene, J.: Moral Tribes: Emotion, Reason, and the Gap Between Us and Them. Penguin Books (2013) 
18. Gürerk, Ö., Irlenbusch, B., and Rockenbach, B.: The Competitive Advantage of Sanctioning Institutions. Science 312:5770, 108-111 (2006)

19. Heberlein, M.: Corona und Handydaten. Mit Tracking zur Bewegungsfreiheit? Tagesschau, https://www.tagesschau.de/inland/corona-handydaten-103.html (Accessed on 12.04.2020)

20. Hock, M.: Die schwärzesten Tage des Dax. Faz.de, https://www.faz.net/aktuell/finanzen/finanzmarkt/traurige-rekorde-dieschwaerzesten-tage-des-dax-16670822.html (Accessedon 27.11.2020)

21. Jervis, R.: Cooperation Under the Security Dilemma. World Politics 30:2, Princeton University Press, Priceton, pp. 167-214 (1978)

22. Komorita, S.S., Chan, D.K., Parks, C.D.: The Effects of Reward Structure and Reciprocity in Social Dilemmas. Journal of Experimental Social Psychology 29, 252-267 (1993)

23. Komorita, S.S., Hilty, J.A., Parks, C.D.: Reciprocity and Cooperation in Social Dilemmas. Journal of Conflict Resolution 35:3, 494-518 (1991)

24. Kurz, C.: Erklärung zur Vorratsdatenspeicherung: „Eingriff in die Privatsphäre von Millionen Menschen“. Netzpolitik.de, https://netzpolitik.org/2016/erklaerung-zurvorratsdatenspeicherung-eingriff-in-die-privatsphaere-von-millionen-menschen/ (Accessed on 23.11.2020)

25. Leopoldina: Coronavirus-Pandemie - Gesundheitsrelevante Maßnahmen. Leopoldina, https://www.leopoldina.org/uploads/tx_leopublication/2020_04_03_Leopoldina_Ste llungnahme_Gesundheitsrelevante_Maßnahmen_Corona.pdf (Accessed: 04.04.2020)

26. Loewenstein, G., Lerner, J.S.: The Role of Affect in Decision Making. Handbook of Affective Sciences. In: Davidson, R.J., Sherer, K.R., Goldsmith, H.H. (eds.) pp. 619-642. Oxford University Press, New York (2003)

27. Loewenstein, G., Schkade, D.: Wouldn't It Be Nice? Predicting Future Feelings. In: Kahneman, D.; Diener, E., Schwarz, N. (eds.) Well-being: The Foundations of Hedonic Psychology. pp. 85-105. Russell Sage Foundation, New York (1997)

28. MacKinnon, D.P., Fairchild, A.J., \& Fritz, M.S.: Mediation Analysis. Annual Review of Psychology, 58, 593-614 (2007)

29. Mitteldeutscher Rundfunk: Spanien schließt "nicht lebenswichtige Unternehmen". MDR.de, https://www.mdr.de/nachrichten/panorama/ticker-corona-virus-samstagachtundzwanzigster-maerz-100.html (Accessed on 20.11.2020).

30. Mellon, J., Prosser, C.: Twitter and Facebook Are Not Representative of the General Population: Political Attitudes and Demographics of British Social Media Users. Research \& Politics, 4:3 (2017)

31. Messick, D.M., Allison, S.T., Samuelson, C.D.: Framing and Communication Effects on Group Members' Responses to Environmental and Societal Uncertainty. Wheatsheaf Books, Brighton, UK, pp. 677-700 (1988)

32. Neuerer, D., Olk, J., Hoppe, T.: Politiker stellen strengen Datenschutz der CoronaWarn-App infrage. Handelsblatt.de, https://www.handelsblatt.com/politik/deutschland/kampf-gegen-die-pandemiepolitiker-stellen-strengen-datenschutz-der-corona-warn-appinfrage/26570478.html?ticket=ST-3222318-FnLZHcl5LYyuavd0R1Vf-ap2 (Accessed on 29.11.2020)

33. Ogburn, W.F.: Cultural lag as theory. Sociology and Social Research 41:3, 167-174 (1957)

34. Orbell, J.M., Van de Kragt, A.J., Dawes, R.M.: Explaining Discussion-induced Cooperation. Journal of Personality and Social Psychology 54:5, 811-819 (1988) 
35. Parks, C.D., Hulbert, L.G.: High and Low Trusters' Responses to Fear in a Payoff Matrix. Journal of Conflict Resolution 39:4, 718-730 (1995)

36. Pavone, V., Esposti, S.D.: Public Assessment of New Surveillance-Oriented Security Technologies: Beyond the Trade-off between Privacy and Security. Public Undestanding of Science 21, 556-572 (2012)

37. Rabin, R.C.: Coronavirus Cases Seemed to Be Leveling Off. Not Anymore. - On Thursday, health officials in China reported more than 14,000 new cases in Hubei Province alone. A change in diagnostic criteria may be the reason. The New York Times, https://www.nytimes.com/2020/02/12/health/coronavirus-cases-china.html (Accessed on 27.11.2020).

38. Reuter, C., Geilen, G., Gellert, R.: Sicherheit vs. Privatsphäre: Zur Akzeptanz von Überwachung in sozialen Medien im Kontext von Terrorkrisen, Informatik 2016: von Menschen für Menschen, Heinrich C. Mayr, Martin Pinzger (Hrsg.), Klagenfurt: GIEdition-Lecture Notes in Informatics (LNI) (2016)

39. Robert Koch Institut: Aktueller Lage-/Situationsbericht des RKI zu COVID-19. RKI Archiv, https://www.rki.de/DE/Content/InfAZ/N/Neuartiges_Coronavirus/Situationsberich te/Gesamt.html (Accessed on 22.11.2020).

40. Senzel, H.: Wie Singapur Handydaten nutzt. Tagesschau, https://www.tagesschau.de/ausland/corona-singapur-app-101.html (Accessed on 12.04.2020).

41. Shaver, L.G., Khawer, A., Yi, Y., Aubrey-Bassler, K., Etchegary, H., Roebothan, B., Wang, P.P.: Using Facebook Advertising to Recruit Representative Samples: Feasibility Assessment of a Cross-Sectional Survey. Journal of Medical Internet Research, 21:8 (2019)

42. Sun, Y., Wang, N., Shen, X.-L., Zhang, J.X. 2015: Location Information Disclosure in Location-Based Social Network Services: Privacy Calculus, Benefit Structure, and Gender Differences. Computers in Human Behavior 52, 278-292 (2015)

43. Tagesschau: RKI prüft mit Handydaten Mobilität. Tagesschau, https://www.tagesschau.de/inland/corona-handydaten-101.html (Accessed on 29.03.2020)

44. Tagesschau: Italien schließt Schulen und Unis, https://www.tagesschau.de/ausland/corona-italien-schulschliessungen-103.html (Accessed: 27.11.2020).

45. Tversky, A., Kahneman, D.: Judgment under Uncertainty: Heuristics and Biases. Science 185:4157, 1124-1131 (1974)

46. Wachs, S.: Ausgangssperre in Frankreich. ARD-Studio Paris, Tagesschau, https://www.tagesschau.de/ausland/frankreich-ausgangssperre-101.html (Accessed on 25.11.2020)

47. Weinstein, N. D.: Unrealistic Optimism about Future Life Events. Journal of Personality and Social Psychology 39:5, 806-820 (1980)

48. Xu, H., Teo, H.-H., Tan, B.C., Agarwal, R.: The Role of Push-Pull Technology in Privacy Calculus: The Case of Location-Based Services. Journal of Management Information Systems 26:3, 135-174 (2009)

49. Yamagishi, T.: Trust: The Evolutionary Game of Mind and Society. Springer, Tokyo (2011)

50. Zhang, B., Mildenberger, M., Howe, P.D., Marlon, J., Rosenthal, S.A., Leiserowitz, A.: Quota Sampling Using Facebook Advertisements. Political Science Research and Methods, 8:3, 558-564 (2020) 